\title{
GUANO MINING IN KENYAN LAVA TUNNEL CAVES
}

\author{
Jim W. Simons *
}

\begin{abstract}
Commercial mining of bat guano for agricultural fertilizer only became possible in Kenya through discovery of major deposits in the lava tunnel caves of Mt.Suswa and the North Chyulu Hills in the early 1960's. This paper provides historical information leading up to the guano mining, describes the cave deposits, outlines the mining under-takings, and provides information on the guano producing bats and insect faunas. The results of guano analyses, details of the the tonnages extracted and sold to recipients between 1966 to 1984, and some benefits which resulted from its use on crops are given. A brief outline of attempts to conserve the areas and caves is also included.
\end{abstract}

Keywords: guano, history of Speleology, Kenya

\section{HISTORICAL INTRODUCTION}

More usually associated with caves in limestone, bat guano has long been recognised worldwide as a source of fertilizer. It has also been mined for less peaceful purposes, as in the U.S.A. where it was dug out of caves to extract nitrates for the manufacture of gun-powder as early as the 1780's, and was in demand for the war of 1812 and for the American Civil War in the 1860's (Halliday, 1966).

In Tanzania, guano was extracted from limestone caves along the Songwe River, near Mbeya (Teale \& Oates, 1935). Here, no less than 2,500 tons of high phosphate material was sold to local agriculture between 1934-1962 (Source - Annual Reports of the Mines Division, Tanganyika). A scamble to obtain the rights over guano in the Machinga Caves of Kilwa, along the Tanzanian coastline, also led to a "Guano Rush" (Bulpin, 1962).

Guano was first extracted in Kenya sometime in the 1930's or 1940's for personal farm use by an enterprising European settler, the late Renshaw Mitford-Barberton, from several caves on the slopes of Mt.Elgon. It was not, however, until exploration in the lava tubes of Mt.Suswa from 1963, and of the northern Chyulu Hills from 1965 onwards (Fig. 1), was it discovered that Kenya possessed substantial guano deposits of value.

Recognising their potential, and that it would not be too long before the accumulations attracted the attention of miners with little or no knowledge of caves and their conservation, three of the original cave explorers registered a company, Kenya Guano Ltd., and made plans for extraction and sale of the deposits while hoping to otherwise minimise damage to the caves and afford them some protection until they could be conserved within National Parks.

As bat guano was then unknown to Kenya's agriculture, and by its nature was a variable product, the new venture had a high investment risk. However, initial laboratory analyses indicated that the deposits were rich in organic matter and contained N.P.K. elements of sufficient percentages that might be sold to Kenya farmers and save on the

\footnotetext{
* Director \& former Mine Manager Kenya Guano Ltd.
} 
then scarce foreign exchange needed for the import of chemical fertilizers. It was considered that a ready market could be established with coffee estates north of Nairobi which were convenient to the rail network.

To be able to commercially extract the deposits under the Mining Act (Laws of Kenya-CAP.306), it first became necessary through the Mines and Geology Department, for guano to be gazetted as a new Kenya mineral based upon its phosphate content, and to obtain a Prospecting Licence. A Consent to Prospect and Mine from Provincial Commissioners and the local district councils was followed by the pegging of Lode Claims, regist-ration of Locations; and authority to proceed to production. The caves were collectively to become refered to as the Kiboko and Mt.Suswa Mines. The company was also obliged to follow the Mining Regulations and file monthly and bi-annual returns of ore produced and sold, its value, and a breakdown of labour and other costs.

At each cave "mine", surveys of the tunnels and the guanos were under-taken. To arrive at estimates of available tonnage, many hundreds of auger-drill holes were laboriously hand-bored into the guano accumulations and samples taken for analyses.

\section{THE LAVA TUNNEL CAVES AND GUANO DEPOSITS}

Lava tunnel caves of international significance were first reported in Kenya on Mt.Suswa Volcano in the Rift Valley in 1963 (Williams, 1963; Glover et. al., 1964). This promoted the formation of the Cave Exploration Group of East Africa in 1964 (Simons, 1964), which led to further studies of that complex system and a search for caves in the Chyulu Hills volcanoes, near Tsavo National Park, where large tubes were soon located in the northern part of the hills (Simons, 1965A, 1972, 1974).

\section{North Chyulu Caves}

Clusters of steep-sided ash cones of the Tindima-Migululu and Kimabui Hills (1,400-1,500 m. a.s.1.), form a lower extension of the main Chyulu range of volcanoes, $160 \mathrm{~km}$. south-east of Nairobi. In the pahoehoe lava flows of this northern outlier lie a series of lava tunnel caves which are south-north trending segments of what was originally a long single tube in a flow which originated from the Makukani Pit Crater in the central cone cluster (Simons, 1974, 1998). Three widely seperated caves were found to contain bat bat guano deposits of significance (Fig. 2).

\section{Kimakia Cave (Ithundu Mine-Locations 130/1 \& 155/1)}

At an altitude of $1,120 \mathrm{~m}$., at the foot of the Kimabui Hills near to the Ithundu Cone, Kimakia Cave was one of the first major lava tubes to be found in the Chyulu Hills in November, 1965 (NGR-415563). Although it has a total of $1.4 \mathrm{~km}$. of passages, the cave is mainly composed of a $1,100 \mathrm{~m}$. long main tunnel which is blocked at both ends. Generally 10 m.across, the tube is frequently "canyon-like" in cross section with roof heights reaching between 12 and $15 \mathrm{~m}$. In the central sector there are three tubes levels, one above the other, with several collapse holes into the upper part. The largest entrance conveniently divides the cave into a $500 \mathrm{~m}$. long northern segment (Imperial Canyon) and a $600 \mathrm{~m}$. long southern segment with a great guano accumulation and was named New Maxwell House from the strong aroma of ammonia. 


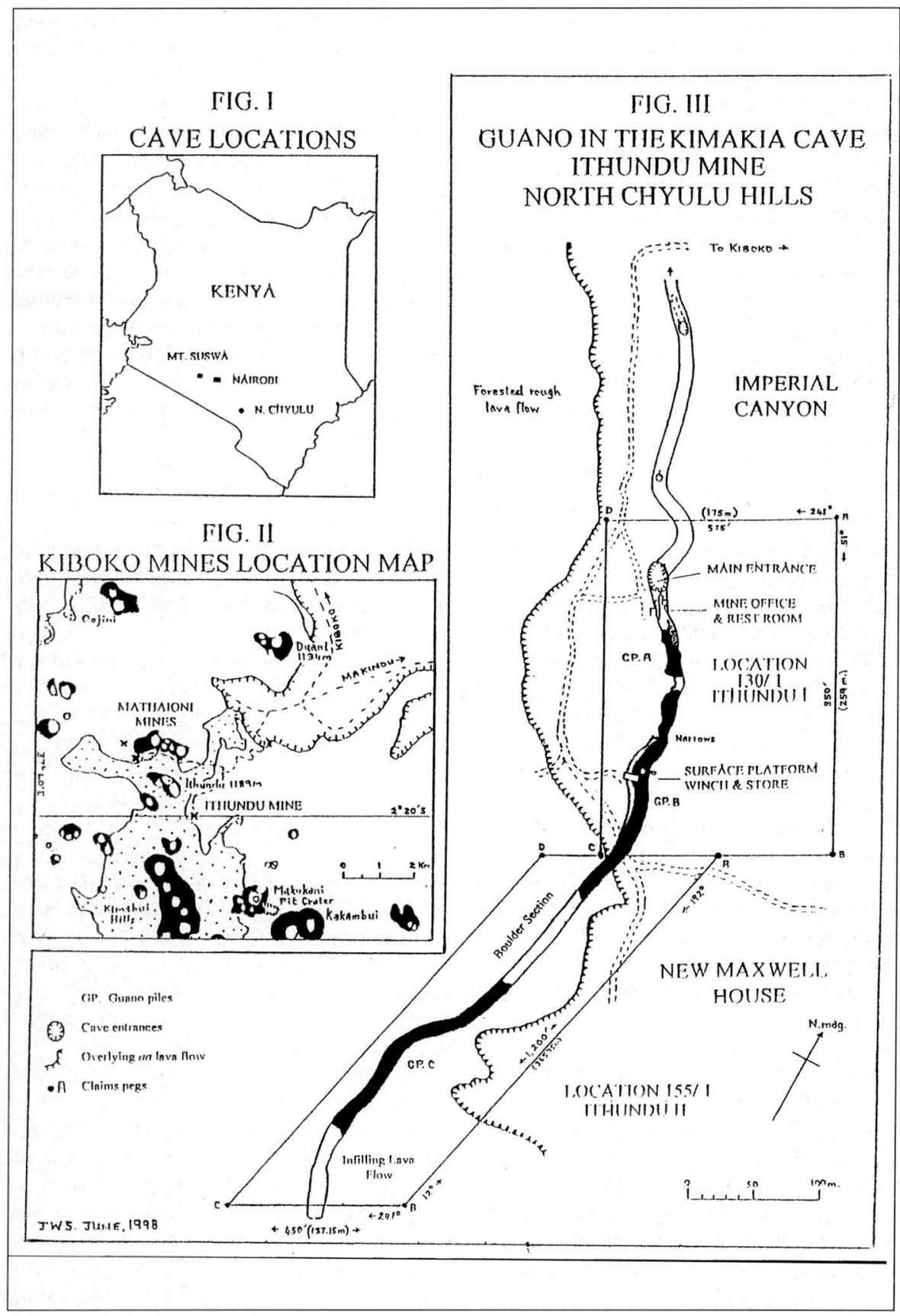

Fig. 1 - Cave locations.

Fig. 2 - Kiboko Mines location map.

Fig. 3 - Guano in the Kimakia Cave Ithundu Mine, North Chyulu hills. 
Claims over the guano were registered in April, 1966 and May, 1968. There were three dusty guano sectors, seperated by boulder piles, which were found to be deepest under the principal bat roosts (Fig. 3):

A) - A short guano sector started $30 \mathrm{~m}$.in from the Main Entrance and extended $35 \mathrm{~m}$. to a roof dome just at the limits of daylight, where there was a mjor bat roost, and reached $1 \mathrm{~m}$.in depth.

B) - The largest accumulation occured between $80-270 \mathrm{~m}$. along the tunnel. Initially, the depth increased inwards from more than $1 \mathrm{~m}$., to $2 \mathrm{~m}$. at the narrows, and attained a maximum depth of $4 \mathrm{~m}$. where the tube widened and formed a $15 \mathrm{~m}$.high domed area and the principal roosting place for thousands of Otomops bats. Here, the accumulation covered a hill of breakdown and then sloped steeply down to continue inwards as a $1 \mathrm{~m}$. deep accumulation before being replaced by a long boulder section occupying the midtunnel area. Before the narrows, a $1.4 \mathrm{~m}$. section of the guano showed some stratification with an $0.8 \mathrm{~m}$. basal layer composed of comparatively loose guano pellets. Conversely, at the deepest level below the dome where there was a small roof hole allowing the ingress of water, the guano formed a wet, grey, clay-like layer of similar thickness. When first augured-into, this released the very pungent odour of sulphuretted hydrogen! Two minerals with probable guano origins were collected. Radiating crystals from the wet clay-like layer were tentively identified by the Late Professor Igor Loupekine as Bobierrite - Mg .P $0.8 \mathrm{H} 0$. A delicate and almost transparent stalactite, filled with blood red liquid, was found at an overhang under a guano-covered ledge and was considered to be a calcium phosphate (Simons, 1974).

C) - A $120 \mathrm{~m}$.long boulder section, which had small guano patches up to $1 \mathrm{~m}$.deep, was followed by a $135 \mathrm{~m}$. long sector of guano ending at $525 \mathrm{~m}$.in from the entrance where rough lava forms an invading flow. Bats have a series of roosts along this fine part of the tunnel and guano varied between $0.3 \mathrm{~m}$ to $1.2 \mathrm{~m}$. deep, with an average of $0.6 \mathrm{~m}$.

\section{Mathaioni Cave (Mathaioni I - Location 360/1-4)}

Mining of the Kimakia Cave guano deposits was already underway when other nearby guano tubes were discovered in July, 1966, $2 \mathrm{~km}$.to the north at the foot of the Mathaioni Cone (Simons, 1972). These deposits were held in reserve and extraction did not take place until 1974.

Mathaioni Cave (NGR-436547) is an extension of Kimkaia Cave, the two being seperated by a gap of roughly $1 \mathrm{~km}$. The cave has around $1.9 \mathrm{~km}$. of passages distributed along a main-line length of $1.4 \mathrm{~km}$. There are also several tube levels one above the other, with three entrances providing entry into the uppermost level. The Main Entrance collapse divides the cave into a $600 \mathrm{~m}$. long southern section (Cairn Passage), which was opened as an attraction in 1974, and an 800 m.long northern section (Boulder Passage). Part way along this segment lies a smaller collapse into a short upper level (Mathaioni Upper), while half-way along there is a depression which was cleared to reveal an $8 \mathrm{~m}$. pitch into the last part of the cave (Exit Pitch). Small insectivorous bats and rather damp guanos were found in humid sections of the cave over which a block of four claims were registered in July, 1974 (Fig. 4):

From "The Pit", roughly a third of the way along the southern tube, a $280 \mathrm{~m}$. long lower tunnel runs beneath Cairn Passage and under the main entrance collapse for $65 \mathrm{~m}$.into the northern tube section. Three guano piles occured: 


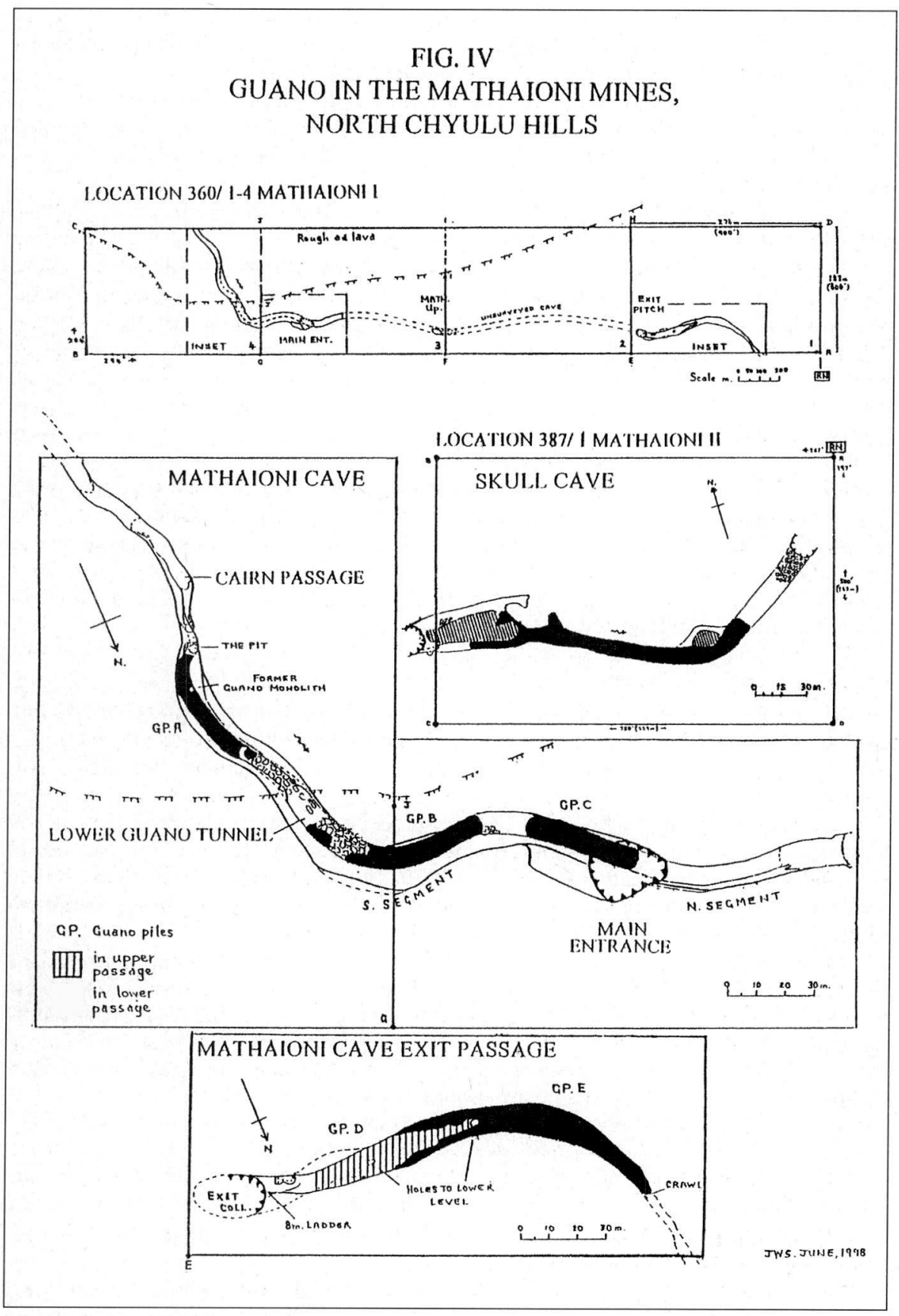

Fig. 4 - Guano in the Mathaioni Mines, North Chyulu hills. 
A) - The first pile commenced at the foot of "The Pit", formed a distinct mound, and ran for $30 \mathrm{~m}$.to peter out at a $2.4 \mathrm{~m}$.drop. It was a little over $2 \mathrm{~m}$. deep and excavation revealed an alternative crawlway into the downstream continuation of the tunnel. A monolith of the guano hill was left standing for further scientific research and as a demonstration section for planned tourist visits into the cave. It remained undisturbed for many years, but in the early 1990's the entire section was regretably stolen by persons unknown and its value to science and posterity forever lost!

B-C)-Roughly mid-way along the lower tunnel were two, rather wet, $1 \mathrm{~m}$. deep piles, with $B$ ) being $60 \mathrm{~m}$. and $\mathrm{C}$ ) nearly $40 \mathrm{~m}$. long.

D-E)-The Exit Pitch led to a $75 \mathrm{~m}$.long upper level floored with guano 15-60 cms.deep (D) and below into the $290 \mathrm{~m}$.long final segment of the cave. Damp guano (E), locally up to 1 m.deep, covered a long boulder breakdown, ending as a deep sloping pile. Removal of this opened up a low crawlway into a $130 \mathrm{~m}$. extension of the tunnel.

\section{Skull Cave (Mathaioni II-Location 327/1)}

On a lower plain, $1 \mathrm{~km}$. north of Mathaioni Cave, are two collapses between which is a $250 \mathrm{~m}$.long passage making up the bulk of Skull Cave. Much of this $10 \mathrm{~m}$. wide tunnel was covered with dry guano up to $60 \mathrm{cms}$. deep over which a single claim was registered in May, 1976 (Fig. 4).

\section{Mt.Suswa Caves}

Mt.Suswa is a shield volcano situated in the middle of the Great Rift Valley, $50 \mathrm{~km}$. north-west of Nairobi. Centrally within its caldera is an impressive collapse graben forming a moat surrounding an "island" block which is unique among the world's volcanoes (McCall \& Bristow, 1965).

In a lava flow which spewed out of the caldera on the eastern flanks of the volcano lie a braided and multi-level system of tunnels which were already well known prior to the commencement of guano extraction in 1970. Nearly 70 collapse entrances provide access to some 40 seperate caves which represent segments of what was a mammoth system totalling more than $11 \mathrm{~km}$.of passages (Simons, 1998).

Principal among the tunnels, is the 14-18 Series or Grand Central System. This complex of $10-20 \mathrm{~m}$ diameter tubes, totals around $3.4 \mathrm{~km}$. of passages and has no less than 8 entrances, several of which segment the system. The series has two upper tunnel sections, those off the $14 \mathrm{~A}-14 \mathrm{C}$ collapses and that connecting the $18 \mathrm{~A}-18 \mathrm{D}$ and 28 entrances, and a lower level which connects the 14 and 18 upper passages by means of several pitches. Guano deposits of various sizes occured in the tubes (Fig. 5).

\section{Upper Series (Suswa I - Location 155/1)}

Guano in the 18 Upper Series was located in two parallel tunnels and a single claim over them was registered in January, 1967:

A) - Many thousands of bats reside in Otomops Passage and, 100m.in from the $18 \mathrm{C}$ collapse, dry guano formed a $140 \mathrm{~m}$.long pile at a bend in the tunnel to end just before a low crawl near a small roof hole (No.28). In places between boulders, it reached depths of more than $2.4 \mathrm{~m}$. One $3 \mathrm{~m}$. deep trench was dug into the south side of the pile by the 
FIG. V

GUANO IN THE 14-18 SERIES, MT. SUSWA MINES, RIFT VALLEY

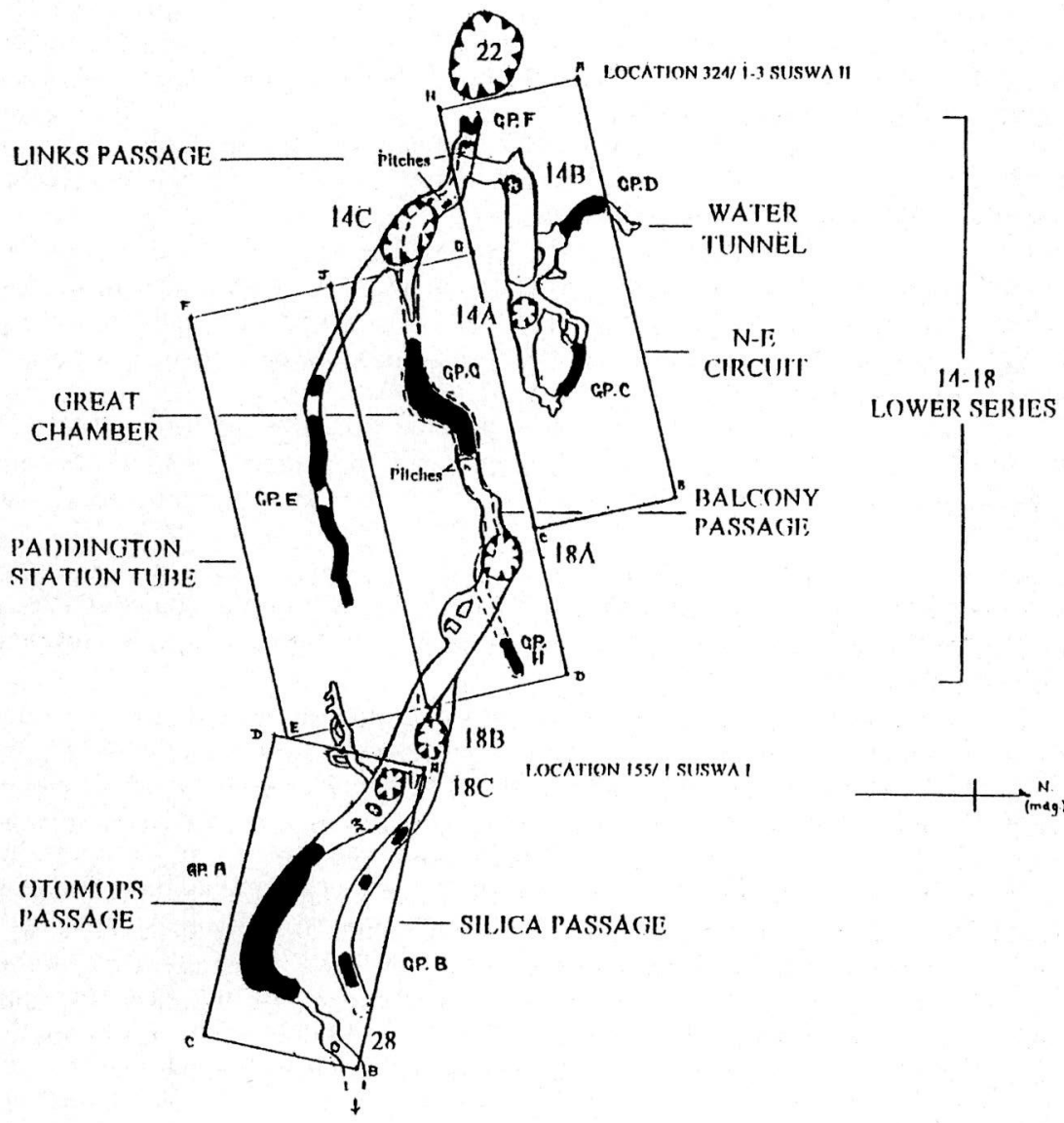

JWS. JINE, 1998

TCH PI.AN

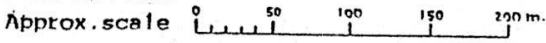

Fig. 5 - Guano in the 14-18 series, Mt. Suswa Mines, Rift Valley. 
author and Dr.P.S.Martin in January, 1966, and samples were collected at every $20 \mathrm{cms}$. for pollen analyses and some went to Geochron Laboratories of Tuscon, USA, for possible $\mathrm{C} 14$ dating. Unfortunately, no feedback on the samples was ever received.

B) - Entered through boulders off the 18B collapse, Silica Passage is a long and rather humid tube which had several small and damp guano piles and colony of hundreds of small insectivorous bats.

\section{A-C \& 14-18 Lower Series (Suswa II-Location 324/1-3)}

Three upper level tube segments contained various guano areas worthy of extraction, with that in a lower level being significant. A block of three claims over the deposits was registered in September, 1972:

C) - One of the 14A N-E Circuit tunnels contained small insectivorous bats and a $30 \mathrm{~m}$. long area of guano with an average depth of little more than $35 \mathrm{~cm}$. and reached a maximum of $0.5 \mathrm{~m}$.in depth.

D) - The 14A-14B Water Tunnel is the seasonal roost of many small insectivorous bats and contained a $75 \mathrm{~m}$.long section of dry guano which increased in thickness inwards from $10 \mathrm{cms}$. up to a maximum depth of $1.3 \mathrm{~m}$. where it formed a hill over the last $30 \mathrm{~m}$. Beyond, a thin and "caked" guano layer had been deposited in what had formerly been a water pool in the mid-1960's.

E) - The $365 \mathrm{~m}$.long Paddington Station passage has Otomops bats and had three areas of damp guano supporting a fairly prolific beetle population. Guano commenced $105 \mathrm{~m}$.in from the $14 \mathrm{C}$ entrance and made up $17 \mathrm{~m}$., $97 \mathrm{~m}$.and $77 \mathrm{~m}$.long sectors with depths reaching $0.75-0.80 \mathrm{~m}$.

Ladder pitches from Links Passage in the 14 Series or from the "Balcony Passage" off $18 \mathrm{~A}$ entrance provide access to the $700 \mathrm{~m}$.long 14-18 Lower Series which had several guano sectors:

F) - A small area beneath the pitch in "Links Passage" had dry guano inbetween boulders from which mummified carcasses of Hyaena, Civet Cat, Rock Hyrax and a rat were recovered (Simons, 1982).

G) - Extensive areas lay mid-way along the passage, either side of a massive boulder fall in the $25 \mathrm{~m}$. wide "Great Chamber" where there is a large colony of Otomops bats. On the west side it formed a steep dusty hill covering rocks to an average depth of $1 \mathrm{~m}$. over a $30 \mathrm{~m}$. distance and reached $1.5 \mathrm{~m}$. deep in places. Lower down on the east side, was a $40 \mathrm{~m}$.long by $12 \mathrm{~m}$. wide area where guano covered the floor to a general depth of $0.7 \mathrm{~m}$. and reached a maximum of $1.4 \mathrm{~m}$. deep. A nearby $10 \mathrm{~m}$. wide bench had guano averaging $0.6 \mathrm{~m}$.deep, while a gully below was filled to a depth of over $1 \mathrm{~m}$. A small $10 \mathrm{~m}$.pile, up to $0.75 \mathrm{~m}$.deep, also lay almost directly beneath a hole in the floor of the higher level Balcony Passage.

$\mathrm{H})$ - At the very end of the 14-18 Lower tunnel, was a 40m.long accumulation with an average depth of $0.5 \mathrm{~m}$.

\section{GUANO EXTRACTION}

Although each site or cave presented its own problems, mining of the accumulations was basically similar. The guano was first shovelled into sacks (Fig. 6A), moved 


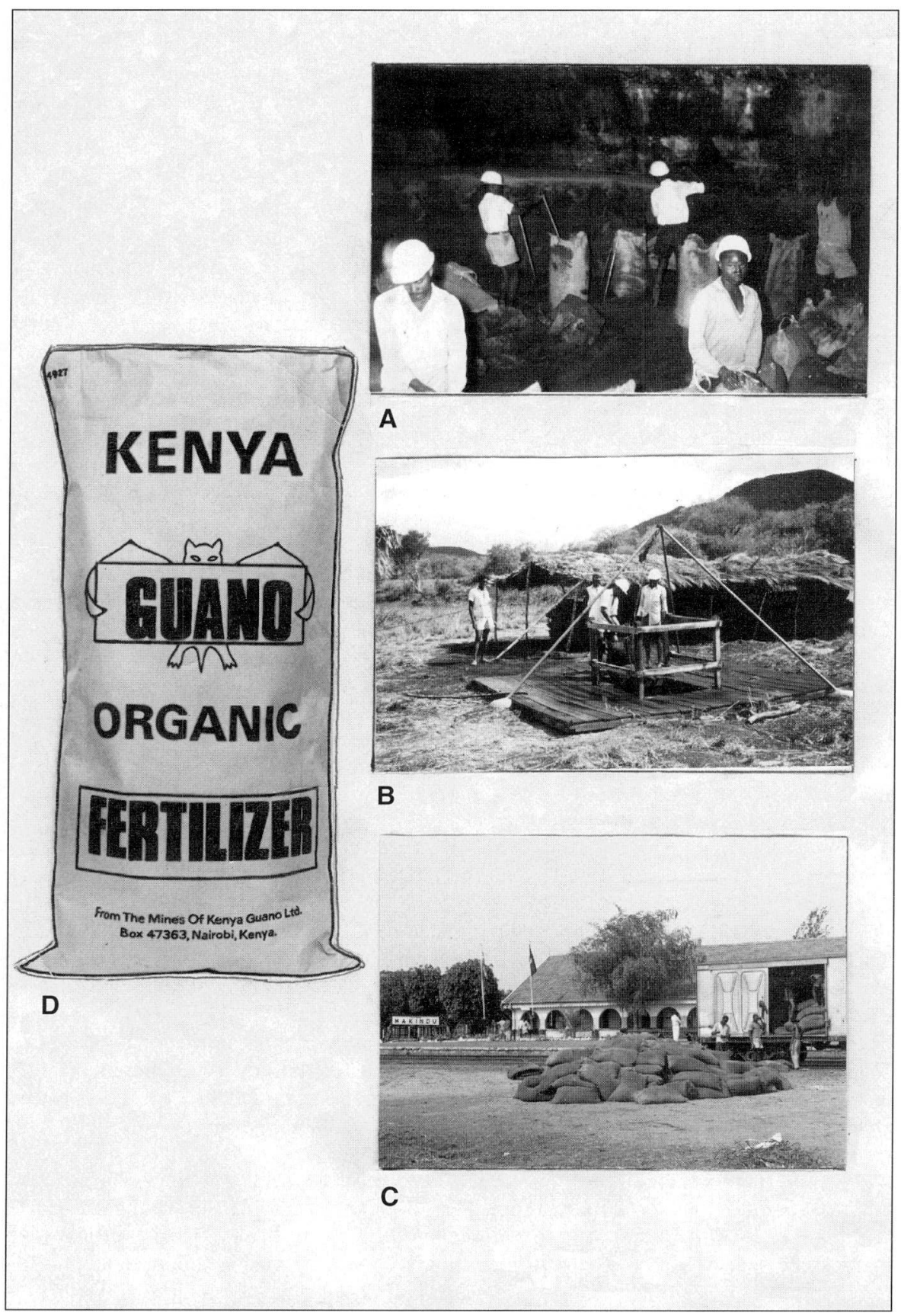

Fig. 6 - Guano mining \& sales activities, Ithundu Mine, North Chyulu Hills.
A) Mining $1,5 \mathrm{~m}$. deep guano in Kimakia Cave.
C) Loading a bulk guano order at Makindu Station.
B) Hoisting guano sacks at Kimakia Cave.
D) A $8 \mathrm{~kg}$ guano bag for retail to home gardeners. 
to entrances and then carried or wire-winched from the caves to surface shelters (Fig. 6B). They were then trans-ported to storage, either near the Makindu or at the Kijabe railway stations, weighed, loaded into waggons and railed to the customer (Fig. 6C). In latter years, some orders were transported directly to estates. Individual sacks and small bags for Nairobi were delivered by company vehicle.

To permit access it was necessary to upgrade bush-tracks into the Kiboko lava flows, up the slopes of Suswa mountain, and pioneer new routes to certain cave entrances (Mathaioni Cave/Hole 28-Mt.Suswa). The caves required preparation to enable removal of the filled sacks by making entrance and tunnel paths, fixing stairs or ladders, installation of ariel rope-ways (Mathaioni Exit/14-18 Lower), and placing of surface platforms and windlasses over convenient roof holes (Kimakia/18 Upper).

All labour was locally contracted and gave work in areas where there was little alternative employment. Between 10 to 50 men might be employed in any one month depending upon orders. At Kiboko, the men camped at the caves, while at Suswa they lived in a compound at the mountain's base.

As a protection against guano dust, miners were supplied with face-masks and in the early years were skin-tested for Pulmonary histoplasmosis by members of the Medical Research Laboratory, Nairobi, and guano samples checked for fungal spores, all with negative results.

Mining of the deposits was undertaken in stages. Once the readily available guano had been removed from a particular tunnel, then another would be opened. As the the resources diminished, so some of the earlier sites would be re-worked and areas "farmed" of new accumulations.

Little treatment of the guanos was necessary beyond seiving out of stone close to the cave floors, and of bat carcasses, beetles and larvae from the top $10 \mathrm{cms}$. of some accumulations. Seiving and pellet break-down was undertaken when re-working the caves of "fresh" accumulations and prior to the filling of small packets destined for Nairobi retail markets. Due to its rather high moisture content, it was considered desirable to sun-dry the guanos from the Mathaioni Cave prior to re-bagging and sale.

\section{THE GUANO PRODUCING BATS}

The largest known colonies of the African Giant Free-Tailed Bat, Otomops martiensenni, occur only in the North Chyulu and Mt.Suswa lava tunnels and it is these bats that have been responsible for the greatest guano accumulations. The biggest single Otomops colony with many thousands of bats is that in the Kimakia Cave in the North Chyulu Hills. Those in the 18 Upper, 14-18 Lower and Paddington Station Passages on Mt.Suswa, are perhaps next in order of size. Studies of the larger colonies took place during 1970-1972 and it was demonstrated that peak pregnancies occured between October and January, with the largest number in November coin-ciding with peak rainfall and a higher abundance of food (Mutere, 1973).

Smaller species of insectivorous bats were also seasonally responsible for the guano accumulations in the other tunnels at both localities. At the Mathaioni Cave, Miniopterus inflatus was present as colonies in the Lower Guano Passage. Probably, it is the same species which occurs in large numbers in the Exit Passage, although a different bat, Miniopterus schreibersi arenarius, was collected at Skull Cave and was presumably responsible for the guano accumulations in that tube.

Many hundreds of Miniopterus (sp.) occupy the 14 Water Tunnel, on Mt. Suswa, and this bat probably accounts for much of the guano in that tube, although a species of 
Rhinolophus has also been collected and may have been a contributor. This bat has also been noted in small numbers at both the Kimakia and Mathaioni Caves, while at the end of the New Maxwell House tunnel was another species, Trianops persieus afer, which occur in some numbers and may have also contributed to the guanos there.

\section{THE GUANO INSECT FAUNAS}

Except in certain tunnels where the Otomops bat predominated, insects on the guanos were suprisingly sparse. In Kimakia Cave, particularly under the major bat roosts and especially within the first $200 \mathrm{~m}$. of the south tube, many thousands of carnivorous beetles were present feeding off dead and moribund bats. Adult, and even new born, bats which had lost hold and fallen to the floor became mired in their own excreta, either to become buried and mummified, or were quickly consumed by the beetles and their larvae to leave gleaming skeletons!

A study of the Ithundu beetle population was undertaken prior to guano removal. From a series of transect samples it was estimated that the densest concentrations probably contained around 1000 beetles per $30 \mathrm{~cm}$. square! Three species of tenebrionid beetle were identified, in order of abundance, as Villersia trivialis, Alphitobius diaperinus and Pogonbasis (peristeptus) marginalis. Less numerous were also one or possibly two species of a dermestid (Attagenus sp.) and a caribid beetle (Somoplatus substriatus). All of these species were also recorded as occuring in the Mt.Suswa caves (McFarlane, 1971). While Pogonbasis was not as numerous at the Kimakia Cave, observations by this author suggest it was the predominant species at Mt.Suswa, at least in the Paddington Station tube where beetle concentrations were found to be greatest.

At the Kimakia Cave, mummified bats, the adult beetles and their larvae, were seived from the guano and returned to the cave floor. Not only was this done as a conservation measure, but it was also considered that the beetles were important to the breakdown of fresh guano pellets through their movement and ingestion. Although numbers have diminished since guano removal, many still do occur in the New Maxwell House segment.

Other species of insects present on the guanos in both cave localities included many fleas, bat parasites, large numbers of acalypterate flys which were attracted to lights, tineid moths, pale crickets with long antennae, small collembola, and pedipulpids (or whip scorpions).

\section{GUANO ANALYSES}

It has to be recognised that Bat Guano, as an entirely natural product and by its location in caves, is a very variable material with the levels of its constituents being influenced by many factors. Among these may be the nature or abundance of the food eaten by the bats, the type of rock in which the caves occur, and the weathering and environmental processes taking place underground at each individual cave. A single deposit of cave guano may vary greatly both laterally and at depth, with the degree by which the accumulation has been locally "leached" or otherwise affected by percolating waters probably playing a major role.

Initially, grab samples were analysed by several Nairobi laboratories to obtain an indication of constituents. For the most part, however, cores from auger drill-holes from the major deposits were "quartered" so as to obtain samples for analysis which would 
be representative of the accumulations as a whole and were submitted to the Government Chemist which department provided a "Certificate of Analysis". The guanos were sold largely upon their high organic content and reasonably balanced percentages of N.P.K. Averages of content were publiscised and bulk-buying customers provided with ranges of analyses on request.

While it is unwise to draw too many conclusions from the analyses, several interesting results have emerged through comparing the guanos of the two localities and from the different types of bats (Table 1,2$)$.

Table 1- Analyses of guano from the Kiboko Mines, North Chyulu Hills

\begin{tabular}{|c|c|c|c|c|c|c|c|c|c|c|c|}
\hline BATS & \multicolumn{3}{|c|}{ Otomops } & & & \multicolumn{4}{|c|}{ Not- Otomops } & & \\
\hline CAVE & \multicolumn{3}{|c|}{ Kimakia Cave } & & & \multicolumn{3}{|c|}{ Mathaioni Cave } & $\begin{array}{l}\text { Skull } \\
\text { Cave }\end{array}$ & & \\
\hline PASSAGE & \multicolumn{3}{|c|}{ South Tunnel } & & & \multicolumn{2}{|c|}{ Exit passage } & $\begin{array}{l}\text { Lower } \\
\text { Tube }\end{array}$ & $\begin{array}{l}\text { Main } \\
\text { Tube }\end{array}$ & & \\
\hline \multirow{2}{*}{ ANALYSES \% } & \multicolumn{3}{|c|}{ SAMPLES } & $\mathrm{R} \triangle \mathrm{NCF}$ & $\Delta \mathrm{V}$ & \multicolumn{4}{|c|}{ SAMPLES } & \multirow[t]{2}{*}{ RANGE } & \multirow[t]{2}{*}{ AV. } \\
\hline & 1966 & $73 / 39$ & $73 / 48$ & NAIVUL & Av. & $74 / 5$ & $74 / 8$ & $74 / 6$ & $76 / 1$ & & \\
\hline Organic & nd & 51.8 & 64.0 & $51.8-64.0$ & 59.7 & 57.5 & 62.5 & 41.0 & 20.4 & 20.4-62.5 & 45.3 \\
\hline Ash & nd & 25.6 & 17.8 & $17.8-25.6$ & 21.7 & 11.4 & 18.4 & 10.4 & 72.2 & $10.4-72.2$ & 28.1 \\
\hline Moisture & nd & 22.6 & 18.2 & $18.2-22.6$ & 20.4 & 31.1 & 19.1 & 48.6 & 7.4 & $7.4-48.6$ & 26.5 \\
\hline Nitrogen N & 13.2 & 6.9 & 11.1 & $6.9-13.2$ & 10.4 & 7.6 & 6.8 & 5.8 & 6.3 & $5.8-7.6$ & 6.6 \\
\hline Phosphate $\mathrm{P}_{2} \mathrm{O}_{5}$ & 11.2 & 12.1 & 8.5 & $8.5-12.1$ & 10.6 & 6.0 & 6.6 & 5.0 & 7.3 & $5.0-7.3$ & 6.2 \\
\hline Potassium $\mathrm{K}_{2} \mathrm{O}$ & 3.5 & 1.3 & 3.1 & $1.3-3.5$ & 2.6 & 2.8 & 0.7 & 2.7 & 2.3 & $0.7-2.8$ & 2.1 \\
\hline Magnesium $\mathrm{MgO}$ & 2.4 & 0.8 & 1.0 & $0.8-2.4$ & 1.4 & 0.7 & 0.3 & 0.8 & 0.7 & $0.3-0.8$ & 0.6 \\
\hline Calcium $\mathrm{CaO}$ & 1.0 & 0.9 & 0.8 & $0.8-1.0$ & 0.9 & 0.2 & 1.4 & 0.4 & 0.8 & $0.2-1.4$ & 0.7 \\
\hline Sulphur $\mathrm{Sa}_{3}$ & 2.9 & 0.8 & 1.0 & $0.8-2.9$ & 1.5 & 2.7 & nd & 2.7 & 0.6 & $0.6-2.7$ & 2.0 \\
\hline Sodium $\mathrm{Na}_{2} \mathrm{O}$ & nd & 0.3 & 0.5 & $0.3-0.5$ & 0.4 & 0.5 & 0.2 & 0.5 & 0.6 & $0.2-0.6$ & 0.4 \\
\hline $\mathrm{pH}$ & nd & 6.5 & 7.7 & $6.5-7.7$ & 7.1 & 6.7 & 4.9 & 6.1 & 6.0 & $4.9-6.7$ & 5.9 \\
\hline
\end{tabular}

Table 2- Analyses of guanos from the Mt. Suswa Mines, Rift Valley

\begin{tabular}{|c|c|c|c|c|c|c|c|c|c|c|c|c|c|c|}
\hline BATS & \multicolumn{8}{|c|}{ Otomops } & & & \multicolumn{2}{|c|}{ Not-Otomops } & & \\
\hline CAVE & \multicolumn{4}{|c|}{18 Upper Series } & \multicolumn{4}{|c|}{ 14-18 Lower Series } & & & $\begin{array}{l}18- \\
\text { Upper } \\
\text { Series }\end{array}$ & $\begin{array}{l}\text { 14A-8 } \\
\text { Upper }\end{array}$ & & \\
\hline PASSAGE & \multicolumn{4}{|c|}{ Otomops Passage } & \multicolumn{4}{|c|}{ Great Chamber } & & & \begin{tabular}{|l} 
Silica \\
Passag
\end{tabular} & $\begin{array}{l}\text { Water } \\
\text { Tunnel }\end{array}$ & & \\
\hline \multirow{2}{*}{ ANALYSIS \% } & \multicolumn{8}{|c|}{ SAMPLES } & \multirow{2}{*}{ RANGE } & \multirow{2}{*}{$\mathrm{AV}$. } & SAI & PLES & \multirow{2}{*}{ RANGE } & \multirow{2}{*}{ AV. } \\
\hline & I & II & III & IV & 1 & 3 & 4 & 10 & & & $74 / 1$ & $72 / 6$ & & \\
\hline Organic & 70.6 & 74.5 & 49.1 & 50.8 & 56.2 & 55.6 & 55.8 & 53.8 & $49.1-74.5$ & 58.3 & 34.8 & 53.4 & $34.8-53.4$ & 44.1 \\
\hline Ash & 18.1 & 18.0 & 40.4 & 45.9 & 21.2 & 21.0 & 20.6 & 16.6 & $16.6-45.9$ & 25.2 & 32.5 & 23.6 & $23.6-32.5$ & 28.0 \\
\hline Moisture & 11.2 & 7.4 & 10.4 & 3.3 & 22.5 & 23.3 & 23.5 & 29.5 & $3.3-29.5$ & 16.3 & 32.7 & 23.0 & $23.0-32.7$ & 27.8 \\
\hline Nitrogen N & 9.6 & 9.8 & 6.6 & 9.4 & 8.0 & 8.5 & 8.6 & 8.0 & \begin{tabular}{|l|}
$8.0-9.8$ \\
\end{tabular} & 8.5 & 3.8 & 7.7 & $3.8-7.7$ & 5.7 \\
\hline Phosphate P2O5 & 9.1 & 8.7 & 16.5 & 19.6 & 8.9 & 9.1 & 8.9 & 7.9 & \begin{tabular}{|l|}
$7.9-19.6$ \\
\end{tabular} & 11.0 & 9.3 & 10.9 & 9.3-10.9 & 10.1 \\
\hline Potassium K2O & 2.2 & 2.0 & 2.4 & 0.5 & 4.9 & 4.7 & 4.5 & 2.7 & \begin{tabular}{|l|}
$0.5-4.9$ \\
\end{tabular} & 3.0 & 1.7 & 3.5 & $1.7-3.5$ & 2.6 \\
\hline Magnesium $\mathrm{MgO}$ & 3.7 & 1.7 & 1.9 & 3.0 & 2.0 & 2.2 & 1.7 & 2.1 & $1.7-3.7$ & 2.3 & 0.9 & 2.9 & $0.9-2.9$ & 1.9 \\
\hline Calcium $\mathrm{CaO}$ & 0.8 & 1.1 & 1.4 & 1.5 & 0.4 & 0.5 & 0.8 & 0.8 & $0.4-1.5$ & 0.9 & 2.8 & 1.1 & $1.1-2.8$ & 1.9 \\
\hline Sulphur Sa3 & 2.4 & 2.7 & 2.5 & 1.4 & 5.6 & 5.0 & 5.9 & 4.5 & $1.4-5.9$ & 3.7 & 3.0 & 4.2 & $3.0-4.2$ & 3.6 \\
\hline Sodium $\mathrm{Na} 2 \mathrm{O}$ & 0.4 & 4.3 & 0.3 & 0,2 & 1.3 & 1.4 & 1.5 & 1.4 & $0.2-4.3$ & 1.3 & 1.0 & 1.0 & $1.0-1.0$ & 1.0 \\
\hline $\mathrm{pH}$ & 7.4 & 7.8 & 6.5 & 6.5 & 6.6 & 6.6 & 6.6 & 6.8 & $6.5-7.8$ & 6.8 & 6.0 & 6.7 & $6.0-6.7$ & 6.3 \\
\hline
\end{tabular}


The guano of the Otomops bat at both localities is found overall to have similar percentages of high organic matter (58\%), Nitrogen (8-10\%), Phosphate (10-11\%) and Potassium (2-3\%). The Magnesium, Sulphur and Sodium content, however, appears to have been somewhat greater in the Mt.Suswa guanos, with the Sulphur element in particular being twice the amount found in the Kiboko Caves, at $3.7 \%$ as opposed to $1.5 \%$. This is largely due to the high percentages in the samples from the 14-18 Lower accumulation. The results may perhaps be attributed to differences in the cave lavas and leaching of a presumed higher Sulphur and Sodium content from the Mt.Suswa phonolites than from the Kiboko basalts.

While the guanos of the smaller insectivorous bats are also similar between the two localities, these appear overall to contain less organic matter (44-45\%) and Nitrogen (6$7 \%$ ) than those of the Otomops bats. The differences might be due to these bats capturing smaller insect prey and contributing less amounts of food with lower nutrients to the caves, or because it so happens that they have favoured tunnels which are little ventilated and humid where higher moisture contents, as in Mathaioni Cave, could have resulted in the leaching-out of the water soluable portion of the Nitrogen element. A lower Phosphate content is indicated in the Mathaioni guanos but the difference is less marked at Mt.Suswa. As with the Otomops guanos, the analyses also show that the Magnesium, Sulphur and Sodium elements are higher in the Mt.Suswa accumulations. With a range of between 6-7, there was little difference in the ph. values between the guanos by both bat type or locality.

\section{GUANO PRODUCTION, SALES RECIPIENTS \& CROP RESULTS}

\section{Production}

The first guano extractions and sales came from the Ithundu Mine with the greatest bulk being removed between April 1966 and April, 1970, following which a move was made to mine the Mt.Suswa caves.

A temporary suspension of activities at Ithundu, however, took place during 1967/8 due to a crisis in the coffee industry when large orders were cancelled. On resumption of mining, stacks of filled sacks which were left in the cave beneath the roof hole had rotted due to the ingress of rainwater and the bags and guano were steaming and hot to the touch! It is known that guano can "burn" and it would seem that the sacks were, like in a haystack, in the process of internal combustion?

By August, 1970, mining from the Mt.Suswa Mines was underway and lasted until 1974. These 5 years were the period of greatest extraction with 1971 and 1972 being the highest period of deliveries. The increased business may be attributed to the success of sales promotions and the product gaining a reputation as being highly beneficial to crops.

The greater part of the 18 Upper deposit was removed between August, 1970 and June, 1972. The whole area was worked over in the latter half of 1972 and again during 1974. The guano accumulations on Location 324/1-3 were mainly worked during 19721974, although small amounts were later extracted and sold in 1977, 1979 and 1984.

With the depletion of easily won material at Suswa, a return was made to the N.Chyulu where sectors of the Ithundu Mine were re-worked from 1973 onwards and extraction at the Mathaioni Cave was commenced late in 1974. The guano piles in this cave were largely exhausted by July, 1977, although further re-working of the areas 
took place in 1978. Extraction at Skull Cave ran during 1976-8, with the guano being sold together with that from the Mathaioni Cave. These two caves were to provide $60 \%$ of the sales tonnage over the 5 years up to 1978 .

Mining of Bat Guano continued for a period of 19 years from 1966 to 1984, although really significant sales only lasted until 1976, by which time most of the easily won deposits had become exhausted, some tunnels had been re-worked, and the business had already become un-economic due to the higher extraction costs. Sales over the following six years were insignificant and barely covered the production costs.

A total of 3,618 metric tons were sold, realising nearly UK $£ 91,000$, with almost equal amounts coming from each cave region (Table 3 ).

Table 3 - Kiboko \& Mt. Suswa Mine production, sales and values

\begin{tabular}{|c|c|c|c|c|c|c|c|c|c|c|}
\hline \multirow[b]{2}{*}{ YEAR } & \multicolumn{4}{|c|}{ KIBOKO MINES } & \multicolumn{4}{|c|}{ KIBOKO MINES } & \multicolumn{2}{|c|}{$\begin{array}{c}\text { TOTAL ANNUAL } \\
\text { PRODUCTION \& SALES }\end{array}$} \\
\hline & $\begin{array}{l}\text { ITHUNDU } \\
\text { MINES }\end{array}$ & $\begin{array}{c}\text { MATHAIONI } \\
\text { MINES }\end{array}$ & $\begin{array}{c}\text { TOTAL } \\
\text { M. TONS }\end{array}$ & $\begin{array}{l}\text { VALUE } \\
\text { K£ }\end{array}$ & $\begin{array}{l}\text { SUSWA I } \\
18 \text { UP }\end{array}$ & $\begin{array}{c}\text { SUSWA II } \\
14-18\end{array}$ & TOTAL & $\begin{array}{l}\text { VALUE } \\
\mathrm{Kf}\end{array}$ & $\begin{array}{l}\text { METRIC } \\
\text { TONS }\end{array}$ & $\begin{array}{l}\text { VALUE } \\
\text { UKE }\end{array}$ \\
\hline 1966 & 169.50 & - & 169.30 & 3081.00 & - & - & - & - & 169.50 & 3081.00 \\
\hline 1967 & 231.00 & - & 231.00 & 4938.00 & - & - & - & - & 231.00 & 4938.00 \\
\hline 1968 & 68.75 & - & 66.75 & 1460.00 & - & - & - & - & 66.75 & 1460.00 \\
\hline 1969 & 275.75 & - & 275.75 & 5303.75 & - & - & - & - & 275.75 & 5303.75 \\
\hline 1970 & 383.00 & - & 383.00 & 6953.50 & 76.00 & - & 76.00 & 1437.00 & 459.00 & 8391.00 \\
\hline 1971 & - & - & - & - & 240.25 & - & 240.25 & 4943.00 & 240.25 & 4943.00 \\
\hline 1972 & 5.00 & - & 5.00 & 346.00 & 591.00 & 152.50 & 743.50 & 15027.00 & 748.50 & 15373.00 \\
\hline 1973 & 135.00 & - & 135.00 & 3107.60 & - & 437.50 & 437.50 & 9107.50 & 572.50 & 12215.00 \\
\hline 1974 & 106.00 & 20.25 & 126.25 & 4472.00 & 126.75 & 100.75 & 227.50 & 6873.75 & 353.75 & 11345.75 \\
\hline 1975 & 65.75 & 233.50 & 299.25 & 11902.50 & - & - & - & - & 299.25 & 11902.50 \\
\hline 1976 & 53.75 & 73.75 & 127.50 & 5914.00 & - & - & - & - & 127.50 & 5914.00 \\
\hline 1977 & 4.00 & 14.75 & 18.75 & 1333.50 & - & 19.75 & 19.75 & 1476.00 & 38.50 & 2809.50 \\
\hline 1978 & 4.50 & 15.25 & 19.75 & 1623.50 & - & - & - & - & 19.75 & 1623.50 \\
\hline 1979 & - & 0.50 & 0.50 & \begin{tabular}{|l|}
51.25 \\
\end{tabular} & - & 5.50 & 5.50 & 557.50 & 6.00 & 608.00 \\
\hline 1980 & - & - & - & - & - & - & - & - & - & - \\
\hline 1981 & 3.00 & - & 3.00 & 306.25 & - & - & - & - & 3.00 & 306.25 \\
\hline 1992 & 1.00 & - & 1.00 & 118.75 & - & - & - & - & 1.00 & 118.75 \\
\hline 1983 & - & - & - & - & - & - & - & - & - & - \\
\hline 1984 & - & - & - & - & - & 6.00 & 6.00 & 624.00 & 6.00 & 624.00 \\
\hline TOTALS & 1504.00 & 358.00 & 1862.00 & 50911.50 & 1034.00 & 722.00 & 1756.00 & 40046.75 & 3618.00 & 90958.25 \\
\hline $\begin{array}{l}\% \text { TOTAL } \\
\text { PRODUCT. }\end{array}$ & $41.5 \%$ & $10 \%$ & $51.5 \%$ & $56 \%$ & $28.5 \%$ & $20 \%$ & $18.5 \%$ & $44 \%$ & & \\
\hline $\begin{array}{r}\% \text { AREA } \\
\text { PRODUCT. }\end{array}$ & $81 \%$ & $19 \%$ & & & $59 \%$ & $41 \%$ & & & & \\
\hline
\end{tabular}

Some 1,862 metric tons was produced and sold from the Kiboko Mines, which repre-sents just over $50 \%$ of the production from all caves. 1,500 tons of this, or more than $40 \%$ of all production, came from the Kimakia Cave alone and this is probably a reflection of the greater size of the Otomops bat population in that single tunnel. Nearly 360 tons was extracted from the Mathaioni I \& II concessions, representing around $10 \%$ of total production. From the Mt.Suswa Mines, over 1,750 metric tons were extracted, of which more than 1,000 tons or nearly $30 \%$ of the entire production, came from the 18 Upper tunnels. The 14 and 14-18 Series of tunnels made up the remaining 
$20 \%$, with at least two-thirds of this being extracted from the 14-18 Lower passage. Again, the largest quantities came from the three Otomops bat tunnels which, all together, produced as much material as the Kimakia Cave.

\section{Sales Recipients \& Crop Results}

The principal value of guano lay in the fact that it was an entirely natural material containing a high organic content and balanced N.P.K. elements. The breakdown of the organic material enabled plants to more readily take-up the other beneficial mineral constituents than would have been the case with applications of manufactured fertilizer.

One drawback was that heavier application rates were generally necessary when compared to chemical fertilizers in order to meet the N.P.K. requirements for a particular crop or farm. This was counteracted by providing the material at a competative price based upon the average N.P.K. percentages in the guanos.

Guano sales may be divided into that which went largely in bulk and direct to the client for the two monsoon rain seasons when fertilizer was generally applied, and amounts which went through Nairobi retailers for onward sale and was mostly in small bag quantities. For the bulk sales, markets were established with Coffee, Tea and Flower growers, which were prepared to pay a free-of-rail price of K.Shs.420/- per metric ton. Discounts were offered on large orders of 50-100 tons.

Over the years, guano was supplied to almost 70 coffee estates in the Nairobi, Kiambu, Kahawa, Ruiru, Thika and Makuyu areas, and as far north as Nyeri. No less than 3,200 m.tons, or nearly $90 \%$ of total guano production, went to coffee with the orders being supplied almost equally from the two mine areas (Table 4).

Tab. 4 - Approximate guano tonnage sold by location and recipients

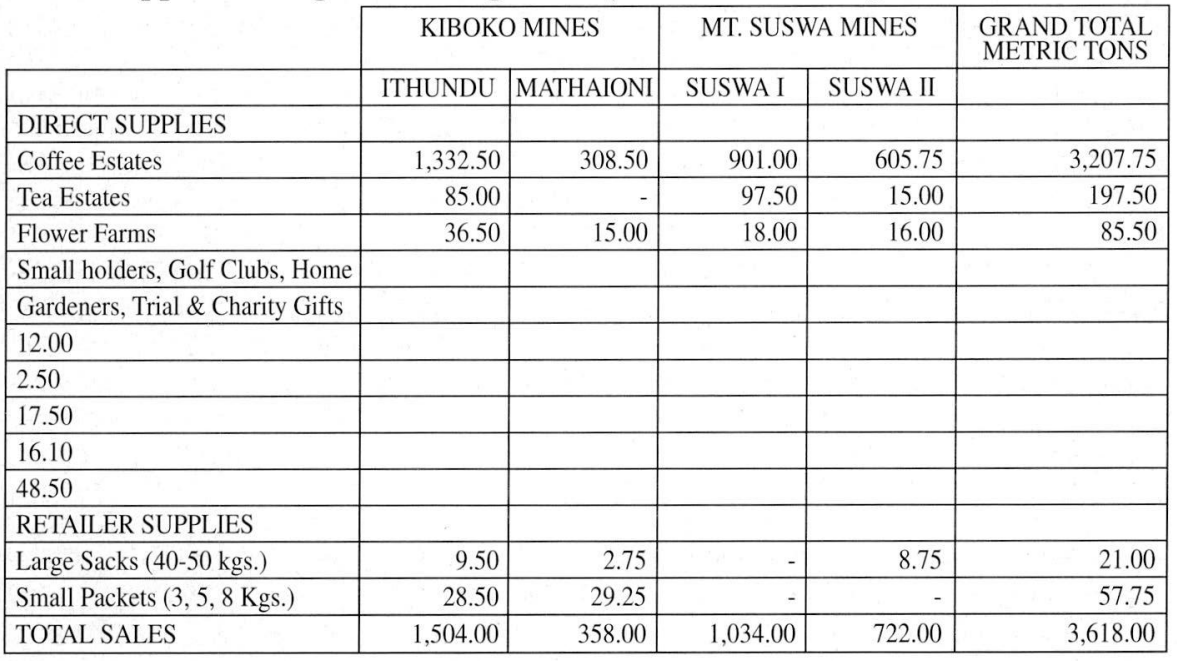

Guano was generally applied to coffee during the rains at a rate of $1 \mathrm{lb} .(0.5 \mathrm{~kg}$.) per tree, often without the addition of any other chemical fertilizer, and would usually be used to provide an organic boost to poorly yeilding blocks. Estate managers frequently commented on the general improvement of the trees, darker and shinier leaf colour, 
increased sucker growth and "spiking". More importently, it was not umcommon to hear that guano treated blocks were producing the best coffee on the estate and giving higher yields!

A trial undertaken on Manyika Estate in 1969 to compare guano applied at a rate of $1.5 \mathrm{lbs}(0.7 \mathrm{~kg}$.) against N.P.K. chemical fertilizers with ratios of $17.17 .17 \& 25.25 .0$ at standared applications, resulted in a slight increase by 12 debbies (standard size tin cans) of coffee per acre on the guano treated blocks. Again, when comparing the results of cattle manure and bat guano, both applied at a rate of $1 \mathrm{lb} .(0.5 \mathrm{~kg}$.) per tree and mixed with basic slag, Kathangi Estate found that the guano block produced a quicker heavy flowering, the trees were in excellant health with no signs of disease or stress, and carried an estimated 1.25 tons of coffee, or well in excess of twice the norm.

A disasterous attack by a fungus, known as C.B.D.(Coffee Berry Disease), in the late 1960's put many coffee estates on the verge of bankruptcy and caused a temporary closure of mining operations during the worst period. However, some estates noted that blocks on which guano had been applied remained healthier and were less affected. The assistance of bat guano in combatting the disease probably contributed to the higher volume of guano sales to that industry in the early 1970's.

A smaller market was found with Tea Estates in the highlands of the Limuru area, north-west of Nairobi, where a little over 190 m.tons were supplied. Smaller quantities of 1 ton. each, also went to the Tea Research Institute and several estates in the Kericho and Sotik area, as well as 1/2 ton to the Tea Research Institute in Tanzania, but these were largely for experimental purposes.

Response to the use of bat guano on tea was similar to that on coffee. Nyara estate, Limuru, reported that during the period September, 1968 - June, 1969, poor plots treated with guano at a rate of 0.5 ton per acre showed a distinct boost, improved leaf, and an increased yeild of $90 \mathrm{lbs}$.of made tea per acre over plots of similar age and condition treated with chemical C.A.N. at 135 lbs. of N.per acre. In 1970, it was reported that guano treated blocks were then the best on the estate and were yeilding an increase of over $300 \mathrm{lbs}$. of made tea per acre!

One custome, near Limuru, annually placed orders for 5-10 tons of guano for intensive flower production and took no less than 85 tons for this purpose. Around 0.5 $\mathrm{kg}$. of guano per sq.m. was mixed with lime, manure and phosphates as required by soil analysis. Performance on carnations was reported to be good and very good on roses and gladioli.

Various African small-holders, golf and sports clubs, schools, plant nursuries, landscape gardeners and home gardeners placed orders ranging from a few sacks up to several tons of material for use in growing vegetables and fruit, for greens and lawns, general flower beds, potted plants and even for growing orchids! Small amounts went gratis to some growers for trials and, by way of promotion, to charities. Sacks were also supplied to a number of Nairobi Garden Centres, usually for onward sale, and accounted for a little over 20 m.tons of production.

Small packets of seived guano from the Kiboko Mines, aimed at the home gardener, were introduced in 1968 . Up to 1973 over 2,000 polythene bags, of $3 \mathrm{~kg}$. and $5 \mathrm{~kg}$.weight were sold direct to retail Garden Centres and vegetable shops in Nairobi, with sales increasing from 1971 as the guano became more widely known. A specially printed and lined $8 \mathrm{~kg}$. paper bag, with a bat emblem (Fig. 6D), was marketed in 1974 and nearly 6000 were sold to retail outlets via a sole distributor up to 1977 when sales were discontinued. During the 9 years, over 8,000 packets were purchased and this alone accounted for nearly 58 m.tons of the production from the Kiboko Mines and made a significant contribution to the company revenue. 
Controlled plots of various vegetables, specifically for small bag sales, were set-up by the company in the Nairobi area in 1968. Guano was applied to the plots at increasing rates from 0 to $5 \mathrm{oz}$. (gm.) and marked growth differences were noted. This led to suggesting a mean rate of around 115 gms.(4 oz.) per square meter, well-watered into the soil, as an optimum application. Too heavy an application could result in "scorching" of the plant roots, stems and leaves. Many home gardeners spoke highly of the results acheived on a wide range of plants and several producers of strawberries were impressed with their yields.

\section{CAVE AREA CONSERVATION}

Mining by Kenya Guano Ltd. provided a temporary means of protecting areas of outstanding natural beauty, their caves and bats, for a period of nearly 20 years. However, it was obvious that this would diminish along with the guano deposits and a permanent means of area and cave conservation has long been sought by this author under various guises.

The uniqueness of Mt.Suswa was recognised as early as the mid-1960's and, while reports to Kenya Government departments calling for the caldera and caves to be set aside as a National Reserve have been submitted (Brown \& Glover, 1969; Simons, 1965B, 1973, 1980), these have so far gone unheeded. The principal problem lies in the fact that the caldera is divided between two Maasai group ranches lying in different districts and agreement on alternative land use is difficult to acheive.

Boundaries to create a national park along the eastern part of the main Chyulu hills were surveyed in the 1970 's, but these ommitted the northern wilderness area and its bat caves. Gazettment occured in 1993 after further area studies and consultant recommendations (Simons, 1980). Inbetween time, the impressive southern segment of the Mathaioni Cave was developed for visitors in 1974. It remained open a semi-wild attraction until 1978, during which time it had received over 700 visitors. This not only added protection to that cave for a time, but also lent weight to calls for the conservation of the area as a whole.

Further attempts were made with the Kenya Wildlife Services to have the northern area protected and the Mathaioni Cave re-developed (Simons, 1992, 1993). Renewed interest was aroused and meetings took place with Government officials during 19921993 which resulted in an agreement that the Chyulu National Park should be extended. But, even as boundary work progressed, illegal squatters invaded and ploughed the area and spoiled its wilderness aspect. In 1996, gazettement was ultimately acheived and the squatters were evicted from the National Park extension. The area, with its caves, is now protected by a ranger sub-station but further development awaits a return to its natural state.

\section{CONCLUSIONS}

Commercial mining of Bat Guano as a source of fertilizer in Kenya became possible through the discovery of significant deposits in the lava tunnel caves of Mt.Suswa Volcano and in those of the Northern Chyulu Hills. Mining of these accumulations by Kenya Guano Ltd. was a pioneer venture which ran from 1966-1984 and, over this 19 year period, no less than 3,500 metric tons of guano was extracted and sold with almost equal amounts coming from the major deposits of the two distant areas. 
Guano was introduced to important agricultural industries, and in the absence of any other purely locally available organic N.P.K. fertilizer, Kenya greatly benefited through the saving of much needed foreign exchange which otherwise would have been spent on chemical fertilizer imports. In addition, the local populaces of the outlying areas also directly benefited through employment, transport hire and general purchases during the period.

Coffee estates purchased the largest guano tonnage and significant amounts also went to Tea and intensive flower farms. Smaller, but no less important, tonnages went to small-holders of various crops, golf clubs and home gardeners, either as directly or as sales through retail garden centres in sacks and small packets of various weights. In all cases, the results of use of the natural organic guano were lauded and was found to be at least as beneficial as some chemical fertilizers and definitely improved crop health, quality and yields.

In the process of mining, much new information concerning the areas and the caves, their bats, guanos and insects was obtained. The company initiated various scientific projects and its activities not only afforded a temporary measure of protection to the principal cave and bat locations, but otherwise brought to Government attention the need for cave area conservation and the concept of cave tourism, some of which has been acheived in the Chyulu Hills, but alas not on Mt. Suswa.

\section{ACKNOWLEDGEMENTS}

In addition to the writer's personal records, much of the content of this paper has been drawn from the archives of Messrs. Kenya Guano Ltd., and grateful thanks are extended to the author's co-directors to freely use this information. Thanks are also due to Miss A.Simons for initial reading and commenting on the manuscript and for other assistance.

\section{REFERENCES}

BROWN, L. and P.E. GLOVER, c.1969. A proposal to establish a chain of National Parks or National Monuments along the length of the Kenya Rift Valley.

BULPIN, T.V. 1962. The Hunter is Death. Nelson. Chap.21 "The Guano Rush": 219-227

GLOVER, P.E., E.C. TRUMP and L.E.D. WATERIDGE, 1964. The Lava Caves of Mount Suswa, Kenya. Stud.Speleol. 1 (1), 1964 (1963): 51-66.

HALLIDAY, W.R. 1966. Depths of the Earth. Harper \& Row (N.York/London). 398 pp.

McCALL, G.J.H. and C.M. BRISTOW. 1965. An Introductory Account of Suswa Volcano, Kenya. Bull. Volcan. 28:333-367.

McFARLANE, J.A. 1971. The Carnivorous Beetles of the Ithundu Caves, Kenya. Stud.Speleol. 2 (3-4), 1971 (1970-1): 149-158

MUTERE, F.A. 1973. A comparative study of reproduction in two populat- ions of the insectivorous bats, Otomops martiensseni, at Latitudes 15 'S and 2 30'S. J.Zool., Lond.(1973), 171: 79-92.

SIMONS, J.W. 1964. The Cave Exploration Group of East Africa. Stud. Speleol.1 (1), 1964 (1963): 73-74.

SIMONS, J.W. 1965 A. Two New caving areas in Kenya. Newsl.Cave Expl. Grp.E.Afr. 3 (Dec.1965): 25-36.

SIMONS, J.W. 1965 B. Discussion on a Proposal to open Mt.Suswa and its Caves as a Tourist attraction and Game Reserve.Min. 17th.Comm.Meet.Cave Expl.Grp.E.Afr., May, 1965: 1-5

SIMONS, J.W. 1972. The Mathaioni Series, North Chyulu Hills, Kiboko, Kenya. Bull.Cave Expl.Grp.E.Afr., 3 : 40-50.

SIMONS, J.W. 1973. Mt.Suswa National Park or Reserve - A Proposal. Mar. 1973: 23 pp. (Private-to Kenya National Parks).

SIMONS, J.W. 1974. The Lava Caves of the Northern Chyulu Hills, Kenya. Stud. Speleol. 2 (6), 1974 (1973): 238-255. 
SIMONS, J.W. 1980. Caves and Cave-Associated Wilderness Areas of Kenya. Background Working Report for Wildlife Planning Unit, Ministry of Environment \& Natural Resources. Submitted by Kenya Caverns \& Lodges Ltd.(Consultants) Apr.1980.

SIMONS, J.W. 1982. Kenya Cave Mummies. Bull.Cave Expl.Grp.E.Afr., 6 (June): 32-37.

SIMONS, J.W. 1992. Tourism Development of the N.Chyulu Hills in Chyulu National Park. Aug.1992, 6pp., 2 maps. (Submitted to Kenya Wildlife Services via Kenya Caverns \& Lodges).

SIMONS, J.W. 1993. Mathaioni Cave, Chyulu Hills National Park. Aug. 1993, 15pp.(Submitted to Kenya Wildlife Services via Kenya Caverns \& Lodges Ltd.)

SIMONS, J.W. 1998. Volcanic Caves of Kenya - A Guide for the 8th. International Symposium on Vulcanospeleology. Privately published, Feb.1998. 37pp. Maps \& plans.

TEALE, E.O. and F. OATES. 1935. The Limestone Caves and Hot Springs of the Songwe River (Mbeya) Area with Notes on the Associated Guano Deposits. Jnl.E.Afr.Uganda Nat.Hist. Soc. 12:

WILLIAMS, L.A.J. 1963. Lava Tunnels on Suswa Mountain, Kenya. Nature, Lond., 199: 348-350. 